\title{
Andragogy and N. F. S. Grundtvig: A critical link
}

\author{
By Clay Warren
}

How has N.F.S. Grundtvig's philosophy of lifelong learning influenced American scholarship in adult education? This article ${ }^{1}$ explores that question by summarizing the ideas of major American philosophers of adult education and the educational philosophy of Grundtvig, by comparing these sets of andragogical guideposts, and by checking for acknowledgement of Grundtvig's contributions. It was decided that Grundtvig has gone essentially unread and unacknowledged in America although his living word had a major effect on E.C. Lindeman who, in turn, passed on this legacy to succeeding adult educators. As a result of this indirect influence, the andragogical assumptions of American adult educators virtually mirror those of N.F.S. Grundtvig.

In the latest, most complete study of the man who has been called the father of adult education in the United States, Stewart (1987) justified re-examining Eduard Lindeman and his ideas about andragogy on the grounds that there is an unprecedented American demand for adult education. Further, "traditional educators in their traditional institutions are taking a new look at their assumptions about adults and about adult learning. As they look to the future with high hopes for their clients, adult educators are looking for philosophical guideposts" (p. 8). Two years on the academic faculty of the International People's College in Elsinore, Denmark, have led me to believe this search for philosophical guideposts must inevitably telescope backward to a Danish philosopher named N.F.S. Grundtvig who, as Stewart also noted, "is relatively unknown except in his native land and the adjoining nations in Scandinavia...[but] has substantially influenced intellectual, social, political, and religious life in many nations outside his own" (p. 115). Is one of these nations the United States or Canada? If Lindeman can be called the father of American adult education, could Grundtvig be called the father of adult education in the Western World? These musings are focused in the following research question: How has Grundtvig's philosophy of lifelong learning influenced American scholarship in adult education? This article will attempt to

1 The final, definitive version of this paper has been published in Adult Education Quarterly, Dec 1989, vol. 39: pp. 211 - 223 by SAGE Publications Ltd. All rights reserved (C) Clay Warren 1989, 2009. 
explore that question by the following route: (a) The ideas of major American philosophers of adult education will be summarized, (b) the educational philosophy of N.F.S. Grundtvig will be set forth, (c) Grundtvig's philosophy of learning will be compared to the andragogical guideposts of the Americans, and (d) a check will be made for acknowledgement of Grundtvig's contributions.

\section{Andragogy in America}

The term andragogy was first introduced to America by Anderson and Lindeman (1927). It took over 40 years, however, for the word to take root. Knowles (1970) defined andragogy as "the art and science of helping adults learn" and developed the concept at length in a wellreceived book. Since then, conceptually-related publications have flowered in profusion. It was no surprise, six years ago, when adult education professors in leading graduate programs at various academic institutions nominated Lindeman's The Meaning of Adult Education and Knowles' The Modern Practice of Adult Education as the two most important contributions to the body of adult education literature (Ilsley, 1983). These works are significant in the search for andragogical guideposts in America, and it is fitting that the fundamental ideas contained therein be given preferred examination.

\section{Lindeman on Adult Learning}

At roughly the same time that he introduced andragogy to America, Lindeman (1926/1961) wrote his first, and only, book on adult education. In its preface, he warned of a principal danger confronting adult education in the United States: "We may 'Americanize' it before we understand its meaning... we have become habituated to a method of achievement which is antithetical to intelligence. We measure results quantitatively" (p. xxx). After this warning, Lindeman expeditiously laid out four assumptions for a new kind of education, assumptions that form the core of his approach to andragogy:

1. Education is life - not a mere preparation for an unknown kind of future living.

2. Education revolves about non-vocational ideals.

3. The approach to adult education will be via the route of situations, not subjects.

4. The resource of highest value in adult education is the learner's experience. (pp. 4-6)

Several scholars have maintained that Lindeman, later in life, radically changed his mind about premise three. For instance, Brookfield (1984) wrote that Lindeman "recanted his earlier assertions and devoted his 
attention to the question of what should be an appropriate curriculum for adult education" (p. 193). This interpretation seems problematic. The "elaboration of curricular concerns" in Lindeman (1945), as cited by Brookfield (1984), are not subjects so much as concerns directly arising from situations. Lindeman (1945) identified these concerns as: "What is to be done about our deep-seated habits of racial discrimination, how are we to democratize our vast educational equipment, how are we to play an appropriate role in world affairs" (p. 12). These items do not constitute a curricular agenda of subjects to be learned but discussion topics for participant-centered learning leading to enlightenment.

The four andragogical assumptions Lindeman set forth may be taken as the core of his philosophy of lifelong learning from start to finish. This core of values, if set into operation by appropriate means, would lead to the end sought by all - enlightenment. "Periods of intellectual awakening are correctly named 'enlightenments' for it is then that lovers of wisdom focus the light of learning upon experience and thereby discover new meaning for life, new reasons for living" (Lindeman, 1926/1961, p. 110).

\section{Knowles on Adult Learning}

Malcolm Knowles has given Lindeman undivided credit for stimulating his own thoughts on adult education:

Eduard C. Lindeman was my first mentor....[The Meaning of Adult Education was] my chief source of inspiration and ideas for a quarter of a century. I still reread it once a year for the inspiration of seeing ideas that were formulated before 1926 that have only in recent times been validated by research. I regard Lindeman as the prophet of modern adult educational theory. (From Knowles' foreword in Stewart, 1987, p. xi)

Thus it is fitting that it was Knowles who developed and popularized the concept of andragogy as a four-part theoretical construct which distinguishes adults' from children's education:

1. As a person matures the self-concept moves from dependency toward self-direction.

2. Maturity brings an accumulating reservoir of experience that becomes an increasing resource for learning.

3. As the person matures, readiness to learn is increasingly oriented towards the person's social roles.

4. As the person matures the orientation towards learning becomes less subject-centered and increasingly problemcentered. (Knowles, 1970, p. 39) 
The similarity of perspective between these two educators, who both regard adult education as learner-centered and best pursued as a collaborative endeavor, is obvious.

\section{Other Thinkers on Adult Learning}

Although those inside and outside America who discuss philosophies of adult education hardly agree on all andragogical principles, virtually all believe that education should be lifelong and that learners should have a greater say in what they learn than is the case in traditional education. Illich (1971), for instance, has written the most vehement and probably best known argument proposing that learners should have autonomy. Freire (1970), a proponent of education for freedom, went so far as to say that teachers first should learn from the students. Perhaps it is an American, Maslow (1971), who most succinctly summed up the ideal lifelong college in which no credits, no required courses, and no degrees would be offered: "A person would learn what he wanted to learn....Education would be available to anyone who wanted it [including] children as well as adults; morons as well as geniuses....The college would be lifelong for learning can take place all through life" (pp. 182-183).

Conti (1985), who reviewed the andragogical literature in his investigation of teaching styles and adult learning, has consolidated those principles common to major philosophers of adult education:

A significantly large portion of the adult education literature supports the collaborative mode as the most effective and appropriate style for teaching adults. In this regard, the writings of Lindeman, Bergevin, Kidd, Houle, Knowles, and Freire exhibit many commonalities. Collectively they argue that the curriculum should be learner-centered, that learning episodes should capitalize on the learner's experience, that adults are self-directed, that the learner should participate in needs diagnosis, goals formation, and outcomes evaluation, that adults are problem-centered, and that the teacher should serve as a facilitator rather than a repository of facts (p. 221).

\section{Grundtvig's philosophy of lifelong learning}

N. F. S. Grundtvig (1783-1872), a Danish theologian-philosopher-poet who resigned twice from clerical duties because of manic-depressive spells, was an intellectual colossus. Throughout his life, by long hours of study and labored exposition, he tried to clarify the relationship among religion, history, and poetry as well as their relationship to people's lives. The result was an enormous body of writing, estimated at 100-150 tomes, most of which is unpublished. 


\section{Philosophical Outlook}

Grundtvig not only thought but wrote his way to philosophical maturity, a process that yielded a library of output filled with internal dissonance. Thus, while Grundtvig's philosophical outlook will be condensed for structural clarity, it must be understood that such a condensation is similar to a two-page outline of War and Peace.

Around the age of 50, Grundtvig at last arrived at a more-or-less satisfactory solution to his problem of defining the relationship between people's lives and the pursuits of religion, history, and poetry. He felt these pursuits were all necessary to people as they ideally lived their lives in mutual freedom accompanied by fellowship; but, while these pursuits should interact freely in life's stewpot, they should never boil down into one amorphous intellectual lump of activity. Grundtvig's Christianity did not subsume history and poetry but operated on an equal level - a remarkable intellectual position for a bishop writing in the mid-I800s. Ultimately, the goal of the pursuits of religion, history, and poetry was enlightenment of life.

Enlightenment of life. While speaking at the folkhighschool named in his honor, Grundtvig (1855) undoubtedly offered his most concise explanation of enlightenment, a term that assumes kingpin status in his philosophy of learning:

In order to learn how to lead a useful and pleasurable human life the majority of people really do not require books at all, but only a good honest heart, sound common sense, a tolerably good ear, a tolerably good tongue, and then enough liveliness to be able to talk to properly enlightened people capable of arousing their attention and showing them what life looks like when the sun shines upon it. (p. 3)

This explanation may seem ironic considering that Grundtvig rarely left his own study, preoccupied as he was with all forms of reading and writing. Nevertheless, the concept of enlightenment constituted the seed of his philosophy which eventually grew to the point where a break with the Christian perspective of redemption - that one must suffer to be redeemed and thereby enjoy a better life in the hereafter was inevitable. Grundtvig believed people must live in the present. Christianity, however, dwelled on the future; books were corpses of the past which he called dead word (Grundtvig, 1832-1855; 1976, p. 20). Living word, on the other hand, sustained people in the present and, as such, will be called the educational operative of enlightenment of life.

The living word. Contrary to the established theological position, Grundtvig came to believe that people do not need to be redeemed by winning God's grace. People inherently enjoy that grace unless they 
reject it by choice, a circumstance that dead-word-oriented systems with confessional and repressive methods were more likely to produce. In an exceedingly difficult decision, a decision that directly affected his church and its Bible, Grundtvig gave his intellectual weight to the side of the living word, maintaining that less emphasis should be placed on written rules and regulations and more emphasis would then perforce flow to the oral interaction of humans seeking enlightenment. This decision undergirded a famous Grundtvigian expression - "First a man, then a Christian" - and accompanied him into an important position on change (Grundtvig, 1976, pp. 140-141).

Change. Years of historical study convinced Grundtvig that the Latin notion of government accepted by much of Westem Europe was wrongheaded. Citizens do not exist for the sake of the state, he felt; instead, the state must be seen as a creation of its citizens. Once created, however, this state would exert pressure to remain static; and, a static entity defies the natural order of things which is change. Citizens, therefore, would have to keep an eye on their creation because the state like religion should always be for, and never before, people. The obvious tool to protect the people, Grundtvig argued, would be the living word. Enlightened dialogue could only promote metamorphosis because one cannot be learning about oneself and succeed in remaining, or indeed wish to remain, the same.

Fellowship and freedom. As previously expressed, "human fellowship and mutual freedom were suggested by Grundtvig to be the underpinning values of a motion-oriented state in which enlightened humans could share life through the living word" (Warren, 1987, p. 7). In contrast to the view that relationships crimp one's freedom, Grundtvig maintained that if one does not have fellowship, one is not free; conversely, if one does not facilitate freedom for self and others, one can never enjoy true fellowship. Without fellowship and freedom, it would be impossible to live an enlightened life and difficult to enjoy the life one did construct.

\section{Philosophical Application}

During his struggle for philosophical maturity, Grundtvig pondered the available educational outlets in which enlightenment of life, the living word, change, fellowship and freedom could be applied. The "black schoo1s" of Denmark, however, resembled the German model which forced people up or out of the system in accordance with their success in emotionless logic and endless memorization channelled all too often through foreign Latinity (Grundtvig, 1976, pp. 151-157). This tyrannical combination, Grundtvig asseverated, would stifle rather than enlighten the human development of any soul. Schools, like 
governments and religions, should serve people and not the other way around. In Grundtvig's (1976) own inimitable words:

It is a high German notion that life is explainable even before it is experienced, and that it must submit itself to change according to the dictum of the learned. Wherever this fanciful idea is incorporated into the educational structure, all such schools become workshops for dissolution and death where the worms live high at the expense of life itself. I completely reject this fanciful notion and maintain that if the school, as an educational institution, is to realize its potentialities for benefiting life, then this school, first of all, should not give the highest priority to purely intellectual activity or to its own institutional status, but set as its chief educational goal the task of helping to solve life's problems. (p. 153)

Since the kind of schools envisioned by Grundtvig did not exist, they would have to be created. These schools would embrace the concepts of enlightenment and folkelighed (freedom of the people). Grundtvig, in fact, hoped these universities would achieve enlightenment through folkelighed and thus called his vision folkehøjskoler (Grundtvig, 18321855). In these folkhighschools, students would be encouraged to bloom rather than be educated to conform. The educational operative of encouragement, the living word, would foster three important interplays: teacher-student, student-student, national poet-educationaI community (see Warren, 1987, 1986, \& 1985).

Teacher-student interplay. Since the Grundtvigian classroom would revolve around competency in life rather than around scholarship, teachers would need more than a thorough knowledge of some subject. They must exhibit nourishing attitudes, an energetic spirit, and dialogical behavior. It would fall upon them to fan each student's spark of life into a flame of vital force through enthusiastic encouragement and give-and-take discussion as equals. Even in his seventies, Grundtvig (1976) strongly believed in the necessity of teacher vitality: "[We must] select the liveliest possible people as teachers" (p. 174). Lectures mostly must be discarded because students were there not only to be taught by teachers but to teach their instructors in turn. According to Bugge (1965), a pre-eminent Grundtvigian scholar in Denmark, this "reciprocal teaching" was Grundtvig's idea of the ideal learning process.

Student-student interplay. Students would not remain in folkhighschools throughout their lives; therefore, it was important to Grundtvig that they learn to carry on the kind of dialogue among themselves that they heard modeled by their enlightened teachers. Without this extension of application, the real world of the students would not be engaged. Further, since people differ in beliefs and behavior, 
Grundtvig was an advocate of diversity in student body makeup to broaden the range of dialogue. This notion was radical to his contemporaries because it encouraged mixing of poor and rich, men and women, of all ages.

National poet-educational community interplay. Depth as well as breadth of enlightenment was necessary to cultivate a student from partial bloom to full blossom. As a poet, Grundtvig knew the difficulty of trying to search the inner recesses of one's being; nevertheless, only this intrapersonal scrutiny could confirm a person's self-appreciation. By poetry, then, he meant a therapeutic and not necessarily aesthetic exchange with oneself: a poetry that would reveal how a "personal interpretation of life and ways of communication [are] necessary in order to intervene and allay the doubts in men's minds that result in despair" (Thaning, 1972, p. 97). As Grundtvig (1976) put it, poetically:

In warmth of sunlight the plants unfold,

And true enlightenment fosters growing;

Of greater value than precious gold

'Tis God and self to be truly knowing. (p. 143)

To model this poetic process, national poets should visit the folkhighschools. Their insight and eloquence would rejuvenate the folkhighschool mission, enlightenment of life through the living word, and would encourage intrapersonal communication in the students.

Folkhighschool model. With these three interplays serving as operational venues of the living word, Grundtvig (1832-1855) postulated a folkhighschool model consisting of at least eight distinct features: (a) Subject matter would not be significant; most important would be if both teacher and students are interested in whatever they choose for study; (b) dialogue should be the tool of instructional communication; (c) no tests, grades, or degrees would be imposed on students; (d) duration of a student's stay would be limited: usually one term of three or four months; on rare occasions, two consecutive terms; (e) students must live at the school during the term; (1) students would work together on some form of physical enterprise; $(\mathrm{g})$ each term's educational community would be self-governing; and (h) teachers would live at the folkhighschool along with the students.

A folkhighschool with these features would help students learn affective and cognitive principles useful in life. At such an educational institution, active contemplation and reflective action would be merged, the enlightened life would be encouraged through the living word, people's lives would be enriched and set free. Throughout their lives people could return to folkhighschools, as either student or teacher, to reinvigorate their sense of self. Such is Grundtvig's philosophy of lifelong learning in capsule form. 


\section{Andragogy vis-à-vis Grundtvig}

Lindeman's and Knowles' andragogical assumptions correlate closely both in content and in number. Indeed, as Stewart (1987) has summarized, "Knowles's own assumptions about adult learning are tailored from Lindeman's earlier model in The Meaning of Adult Education" (p. 6). Refining this basic four-part construct along lines developed by other leading adult educators in America, an integrated position is produced. This summary may be juxtaposed against Grundtvig's philosophy of lifelong learning as consolidated into a quadratic set for ease of comparison. Table 1 presents the result.

\section{Table 1}

Comparison of Andragogical Assumptions of American Adult Educators and N. F. S. Grundtvig

\begin{tabular}{|l|l|}
\hline $\begin{array}{l}\text { Assumptions: American Adult } \\
\text { Educators }\end{array}$ & Assumptions: N.F.S Grundtvig \\
\hline $\begin{array}{l}\text { Because education should be } \\
\text { learner-centered, the learner's } \\
\text { experience is the greatest } \\
\text { resource. }\end{array}$ & $\begin{array}{l}\text { Students should bloom according } \\
\text { to their individual capacity and } \\
\text { not be crushed into conformity by } \\
\text { externally-derived ideals. }\end{array}$ \\
\hline $\begin{array}{l}\text { Study should be problem- or } \\
\text { situation- rather than subject- or } \\
\text { vocation-oriented. }\end{array}$ & $\begin{array}{l}\text { Subject matter is not important; } \\
\text { study should be chosen according } \\
\text { to interests and should be geared } \\
\text { toward personal growth rather } \\
\text { than scholarship. }\end{array}$ \\
\hline $\begin{array}{l}\text { Teachers should be facilitators of } \\
\text { discussion rather than inculcators } \\
\text { of facts. }\end{array}$ & $\begin{array}{l}\text { Reciprocal teaching is the ideal } \\
\text { learning process engaged through } \\
\text { the living word. }\end{array}$ \\
\hline $\begin{array}{l}\text { Learning is motivated by a } \\
\text { mature desire to understand and } \\
\text { to assume roles in society; thus, } \\
\text { learning can be equated with life } \\
\text { itself. }\end{array}$ & $\begin{array}{l}\text { The ultimate reason for learning } \\
\text { is enlightenment of life - the } \\
\text { grasp of religious/historical/ } \\
\text { poetic knowledge of one's world, } \\
\text { and thus of one's self, integrated } \\
\text { through both freedom and } \\
\text { fellowship. }\end{array}$ \\
\hline
\end{tabular}

\section{Acknowledgement of Grundtvig's influence}

Just as Knowles has given credit to Lindeman for being a primary heuristic stimulus, one expects scholars to acknowledge the sources 
behind their development. Has Grundtvig been given such acknowledgement? Let us look first and primarily at Lindeman to answer this question, then touch briefly on other major American adult educators to flesh out the picture.

\section{Lindeman and Grundtvig}

Lindeman (1926/1961) clearly was passionate in his regard for adult education in Denmark:

In Danish life...one finds an educational ferment such as motivates no other people in the modern world. Since the days of Grundtvig...Danish adults have striven to close the yawning abyss between life and enlightenment [by laying] the foundations for a system of education which continues so long as life lasts. Adult education, one begins to learn after prolonged observation, has not merely changed citizens from illiteracy to literacy; it has rebuilt the total structure of life's values. (pp. xxix-xxx)

Kidd corroborated this Danish influence on Lindeman in the foreword to the reprinted edition of The Meaning of Adult Education: "His visits to Denmark, the homeland of his parents, affected him profoundly as is clear from the present book" (quoted in Lindeman, 1926/1961, p. xxiii). Later in life, Lindeman (1945) wrote: "The chief source of Denmark's economic and social renaissance [is the folkhighschool] and hence it was that I came back from Denmark a convinced and ardent advocate of adult education" (p. 4). Stewart (1987) not only has identified eight threads of influence on Lindeman originating from Grundtvig, he has stated unequivocally that "living in freedom, as well as learning in freedom, was a topic developed by Lindeman in a full chapter of The Meaning of Adult Education. Grundtvig's philosophy...jumps from every page" (p. 126). Indeed, Lindeman knew and approved the use of Grundtvig's enlightenment (vide supra) to describe the goal of education.

Despite the obvious and admitted influence of Danish andragogy on Lindeman, Grundtvig himself was only once mentioned in The Meaning of Adult Education and never quoted. It is not as if Lindeman were averse to quoting others, since he freely quoted such scholars as Dewey, Santayana, and Whitehead. (Further, given Lindeman's selfavowed Danish ancestry, it is odd that his spelling of people's colleges was the German Volkshochschulen [p. xxx] rather than the Danish folkhøjskoler.)

Stewart (1987) offered two reasons to explain the quotation anomaly. First, Lindeman "could not have read Grundtvig's essays and writings, since few were available in English translation until $1976 . . . c o n s e q u e n t l y$, he seldom or never quoted Grundtvig directly" 
(p. 127). This reason seems sound, since Grundtvig's writings are difficult to find in print let alone in English, although once again one might question why Lindeman's alleged Danish ancestry could not have solved the language problem. Stewart has addressed this question with the help of previously unavailable family sources: "Eduard was certainly of German descent by birth....Denmark served a deep psychological need in Lindeman, the need to be something other than German by heritage" (p. 129). Lindeman's invented roots were so reliably referenced in his writing and speaking that only recently has this question been clarified and not even Kidd, while composing the foreword partially cited earlier, would have known otherwise.

The second reason provided by Stewart is more speculative: "There may have been another reason for Lindeman's less overt philosophical tie with Grundtvig. Perhaps he did not wish to be identified with...the great philosopher's pervasively Christian theological edifice" (p. 127). This explanation is hard to accept. For one thing, although Grundtvig was a priest, he was neither fanatically nor even conventionally religious: "Grundtvig's view of Christianity has no parallels in the history of the Church....He did not feel himself to be a professional theologian, but on behalf of human life he was strongly critical of all accepted theology" (Thaning, 1972, p. 142). Lindeman probably would have enjoyed sharing such an iconoclastic position. Moreover, when Lindeman changed his name in college, he assumed the middle name of Christian. Such a choice may not have been entirely free of religious overtones.

It seems safe to say that Lindeman did not quote or often mention Grundtvig, as he did other sources of influence, because he had not read the Dane's writings. He undoubtedly had heard a great deal about Grundtvig's ideas during his trips to Denmark, however, and it is this philosophy that has most profoundly "enlightened" his own andragogical core of values. Grundtvig likely would have been pleased to know that his philosophy would have such an effect on the father of American adult education, not through the written but through the living word.

\section{Other American Adult Educators and Grundtvig}

Stewart (1987) has documented the difficulty of researching Grundtvig from English sources at hand:

I faced a major - and insurmountable - hurdle in trying to define Nickolai Grundtvig only from review of those small portions of his work that have been translated into English. It became apparent that research into previously untapped (in this country) Danish language sources was essential. (p. xvi) 
And yet, notwithstanding this proclamation and his generally thorough research, Stewart referenced and quoted only Grundtvig resources already available in English (e.g. Bugge, 1965). Also, and inexplicably, he never referenced Kaj Thaning, Grundtvig's official biographer whose work is available in English through the Danish Institute.

A review of other major American adult educators' work reveals a similar lack of direct knowledge or acknowledgement of Grundtvig's philosophy of lifelong learning. One will not obtain information about Grundtvig by reading Kidd (1959/1973), Bergevin (1967), Knowles (1970), or Houle (1972) where, for instance, one finds the following explanation and promise concerning the documentation underlying the book's premises:

The [adult education] system proposed here owes much to the growth of thought in adult education and the credos and systems which have been widely espoused as guides to practice...the analysis of these topics rests on an elaborate documentary study which is summarized in the bibliographic essay at the end of the book. (p. 3)

This otherwise well-done 66-page documentary section included not a single work by Grundtvig. In the body of the book, Houle mentioned Grundtvig only twice and briefly, both times in the context of describing the role of powerful leadership through the aid of the living word, a term he did not define.

Not long ago, Axford (1985) offered a paper about the impact of Grundtvig on adult educators. Although at the outset he quoted Peter Manniche, founder of the International People's College, as having established the institution based on "the writing of N.F.S. Grundtvig" (p. 8), there is little direct evidence cited of whether Grundtvig's writings were read and critically evaluated by listed American adult educators (e.g., Knowles, Bergevin, Kidd). What is found, instead, are claims that Kidd "was much influenced by the thinking" of Grundtvig and that Kulich "gives credit to Grundtvig's influence on his philosophy and programming in adult education" (p. 7). When the work of Kulich (1979) is discussed, however, one finds a study not of Grundtvig's written philosophy but of Danish and Polish folkhighschools (see also Kulich, 1984).

In short, Grundtvig and his philosophy of lifelong learning have not been critically examined or acknowledged in the literature of American adult education. His influence, on the other hand, indirectly has reached almost every adult educator, primarily through Lindeman's mediation of ideas, secondarily through the model of Danish folkhighschools. As Friedenthal-Hasse (1987) noted in Germany, which is also true in America, Grundtvig's "influence was felt through 
the effects of his life and indirectly through his practical work, not through a direct assimilation of his written work" (p. 17).

\section{Conclusion}

That Grundtvig has gone unread and unacknowledged is understandable. His 150-tome library of output would daunt even dedicated scholars who speak his language (as it has those in Denmark) and, since much of this library is unprinted, his writings are not easy to collate. With material that has been collected, one faces the formidable challenge of Grundtvig's internal dissonance, complex ideologies, and idiosyncratic use of the Danish language. Finally, if one cannot read Danish, the problem expands geometrically because of the measurably few translations available (see Education for Life, 1983; Thodberg \& Thyssen, 1983).

And yet, some of Grundtvig's work is available in English. Moreover, more of his writings should be made available in the years to come. Kierkegaard's writing is not easy to read, either, and it is readily obtainable all over the world.

It would be unfair to the nature of scholarship to continue to ignore Grundtvig's critical link with andragogy by foregoing a critical examination of his verbal heritage. Particularly in America, whose father of adult education was so demonstrably influenced by Grundtvigian living word, and whose adult educators are actively searching for philosophical guideposts, we need to correct this situation and give Grundtvig his due both in reference documentation and by reading his work. Lykønskning til Danmark med Det Danske Dummerhoved og Den Danske Høiskole (Congratulations to Denmark on Danish Thickheadedness and the Danish Highschool), for example, is ideologically interesting, humorously ironic, and uplifting. It would be a loss to us never to directly enjoy the stature and the wit of Grundtvig's mind.

\section{References}

Anderson, M. L., \& Lindeman, E. C. (1927). Education through experience. New York: Workers Education Bureau.

Axford, R (1985, July). The impact on [sic] N. F. S. Grundtvig (on adult educators). Paper presented at Adult Education Association conference, Tempe, AZ (ED-2S4627).

Bergevin, P. (1967). A philosophy for adult education. New York: Seabury.

Brookfield, S. (1984). The contribution of Eduard Lindeman to the development of theory and philosophy in adult education. Adult Education Quarterly, 34, 185-196. 
Bugge, K. E. (1965). Skolen for livet: Studier over N. F. S. Grundtvigs predagogiske tanker [The school for life: Studies on N. F. S. Grundtvig's pedagogical thoughts]. Copenhagen: Institut for Dansk Kirkehistorie. (English language summary included).

Conti, G. J. (1985). The relationship between teaching style and adult student learning. Adult Education Quarterly, 35, 220-228.

Education for life. Proceedings of the International Conference on the Occasion of the Bicentenary of N. F. S. Grundtvig. (1983). Copenhagen: Det Danske Selskab.

Friedenthal-Haase, M. (1987). N. F. S. Grundtvig and German adult education: Some observations on the intercultural reception of theory. Studies in the Education of Adults, 19(1), 13-25.

Freire, P. (1970). Pedagogy of the oppressed. New York: Seabury.

Grundtvig, N. F. S. (1976). Selected writings: N. F. S. Grundtvig. (J. Knudsen, Ed. \&. Trans.). Philadelphia: Fortress.

- (1832-1855). [Collected papers on the folkhighschool, including portions of Lykønskning til Danmark med Det Danske Dummerhoved og Den Danske Høiskole). Elsinore, Denmark: International People's College. Mimeographed manuscripts.

Houle, C. O. (1972). The design of education. San Francisco: Jossey-Bass.

Illich, I. (1971). Deschooling society. New York: Harper \&. Row.

Ilsley, P. (1983). The relevance of the future in adult education. Proceedings of the Adult Education Research Conference, 24, 124-129.

Kidd, J. R (1973). How adults learn. New York: Association Press. (Original work published 1959).

Knowles, M. S. (1970). The modern practice of adult education: Andragogy versus pedagogy. New York: Association Press.

Kulich, J. (1984). N. F. S. Grundtvig's folk high school idea and the challenge of our times. Lifelong Learning, 7(1), 10-13.

- (1979). The Danish and the Polish folk high schools: A comparative analysis. Vancouver, B.C.: University of British Columbia, Center for Continuing Education.

Larson, D. G. (1970). A comparison of the spread of the folk high school idea in Denmark, Finland, Norway, Sweden and the United States. Doctoral dissertation, Indiana University, Bloomington.

Lindeman, E. C. (1945). The sociology of adult education. Journal of Educational Sociology, 19(1), 4-13.

- (1961). The meaning of adult education. Montreal: Harvest House. (Original work published 1926).

Maslow, A. (1971). The farther reaches of human nature. New York: Viking. Parke, K. (1917). The folk college in America. Rochester, NY: Cricket.

Stewart, D. W. (1987). Adult learning in America: Eduard Lindeman and his agenda for lifelong education. Malabar, FL: Krieger.

Thaning, K. (1972). N. F. S. Grundtvig (D. Hohnen, Trans.). Odense, Denmark: Det Danske Selskab.

Thodberg, C., \& Thyssen, A. P. (Eds.). (1983). N. F. S. Grundtvig: Tradition and renewal. Copenhagen: Det Danske Selskab. 
Warren, C. (1987). Grundtvig's philosophy of lifelong education through the living word (Occasional Paper No. 3). Sydney, Nova Scotia: University College of Cape Breton Press, Tompkins Institute for Human Values \& Technology.

- (1986). Grundtvig's philosophy of learning and its relevance to applied humanistic education. Journal of Humanistic Education, 10, 26-29.

- (1985, March). Therapeutic roles of the living word: A homily on Grundtvigian philosophy in contemporary Denmark. Paper presented at 2nd conference on Communication Therapy, Houston, TX. 